\title{
Association of Serum Progranulin Levels with Progression of Papillary Thyroid Cancer
}

\author{
Won Gu Kim
}

Division of Endocrinology and Metabolism, Department of Internal Medicine, Asan Medical Center, University of Ulsan College of Medicine, Seoul, Korea

Recent epidemiological studies have reported a strong association between obesity and thyroid cancer, especially papillary thyroid carcinoma (PTC) [1,2]. Data from a recent meta-analysis of 22 prospective studies suggested that overweight and obese individuals have $25 \%$ and $55 \%$ higher risks of thyroid cancer, respectively, than their normal-weight counterparts [2]. Some evidence exists regarding a potential association of overweight and obesity with more aggressive clinical and pathological characteristics in patients with thyroid cancer [3]. These findings underscore the need to study potential mechanisms implicated in the effects of obesity on the process of thyroid carcinogenesis and cancer progression. Various molecular pathways may explain the underlying mechanism of obesity-induced carcinogenesis and cancer progression because obesity can cause complex and diverse metabolic changes. Insulin resistance, augmented insulin-like growth factor 1 signaling, increased oxidative stress, increased levels of free fatty acids and other macromolecules, and changes in cytokine and adipokine levels may contribute to the carcinogenesis, progression, and metastasis of thyroid cancer [3]. In obesity, decreased levels of anti-inflammatory adipokines, such as adiponectin, and increased levels of pro-inflammatory adipokines, such as leptin and resistin, can stimulate or suppress several signaling pathways associated with thyroid carcinogenesis [4].

In this issue of Endocrinology and Metabolism, Kwon et al. [5] evaluated the serum levels of two important adipokines, adi-

Received: 1 June 2020, Accepted: 10 June 2020

Corresponding author: Won Gu Kim

Division of Endocrinology and Metabolism, Department of Internal Medicine, Asan Medical Center, University of Ulsan College of Medicine, 88 Olympic-ro 43-gil, Songpa-gu, Seoul 05505, Korea

Tel: +82-2-3010-5883, Fax: +82-2-3010-6962, E-mail: wongukim@amc.seoul.kr ponectin and progranulin, in patients with PTC. They included 131 patients with PTC and 26 patients with confirmed benign thyroid nodules after thyroid surgery. The median level of serum adiponectin was 5.4 and $6.3 \mu \mathrm{g} / \mathrm{mL}$ in the PTC group and the benign nodule group, respectively. However, this difference was not statistically significant. In patients with PTC, serum adiponectin levels were not associated with clinicopathological parameters, including primary tumor size, cervical lymph node metastasis, extrathyroidal extension, and multifocality. These results on serum adiponectin levels in PTC patients are consistent with those of a previous study that evaluated serum adiponectin levels and the expression of its receptor in patients with PTC [6]. That study suggested that adiponectin receptor expression in tumor tissue, but not serum adiponectin levels, played an important role. A significant negative correlation was found between adiponectin receptor expression in tumor tissue and poorer pathological parameters, including multifocality, extrathyroidal extension, and advanced tumor-node-metastasis (TNM) staging [7]. These findings suggest that serum adiponectin levels per se are not an important factor explaining the potential mechanism through which obesity influences the carcinogenesis of PTC.

Kwon et al. [5] also evaluated the serum levels of progranulin, an adipokine implicated in diverse biological processes in embryogenesis, inflammation, insulin resistance, and carcinogenesis [8]. This is the first study to report a potential role of progranulin in thyroid carcinogenesis. The median serum progranulin

Copyright $\odot 2020$ Korean Endocrine Society

This is an Open Access article distributed under the terms of the Creative Commons Attribution Non-Commercial License (https://creativecommons.org/ licenses/by-nc/4.0/) which permits unrestricted non-commercial use, distribution, and reproduction in any medium, provided the original work is properly cited. 
level was 106.1 and $101.5 \mathrm{ng} / \mathrm{mL}$ in the PTC group and benign nodule group, respectively. The median progranulin level was significantly higher in patients with PTC greater than $1 \mathrm{~cm}$ than in those with micro-PTC. The proportion of patients with microscopic and gross extrathyroidal extension significantly increased with serum progranulin quartiles. These findings suggested that progranulin, a cysteine-rich secretory protein, may be a potential biomarker and therapeutic target of PTC. Progranulin is known to be as a growth factor implicated in tumorigenesis and a poor prognostic marker in breast cancer, non-small cell lung cancer, astrocytoma, glioblastoma, cervical cancer, and biliary tract cancers [8]. However, the mechanism of action through which progranulin contributes to carcinogenesis is unclear because the signaling receptor is still elusive. Recently, several candidate receptors such as sortilin, tumor necrosis factor receptor, and ephrin type-A receptor have emerged as potential links involved in the action of progranulin $[9,10]$. The potential association of progranulin upregulation with poorer pathological parameters of PTC might facilitate further research into the possible value of progranulin as a biomarker and therapeutic target.

\section{CONFLICTS OF INTEREST}

No potential conflict of interest relevant to this article was reported.

\section{ORCID}

Won Gu Kim https://orcid.org/0000-0002-8404-7759

\section{REFERENCES}

1. Schmid D, Ricci C, Behrens G, Leitzmann MF. Adiposity and risk of thyroid cancer: a systematic review and metaanalysis. Obes Rev 2015;16:1042-54.

2. Kitahara CM, McCullough ML, Franceschi S, Rinaldi S, Wolk A, Neta G, et al. Anthropometric factors and thyroid cancer risk by histological subtype: pooled analysis of 22 prospective studies. Thyroid 2016;26:306-18.

3. Kim WG, Cheng SY. Mechanisms linking obesity and thyroid cancer development and progression in mouse models. Horm Cancer 2018;9:108-16.

4. Marcello MA, Cunha LL, Batista FA, Ward LS. Obesity and thyroid cancer. Endocr Relat Cancer 2014;21:T255-71.

5. Kwon H, Park SE, Yun JS, Park CY. Serum Adiponectin and progranulin level in patients with benign thyroid nodule or papillary thyroid cancer. Endocrinol Metab (Seoul) 2020; 35:396-406.

6. Pazaitou-Panayiotou K, Panagiotou G, Polyzos SA, Mantzoros CS. Serum adiponectin and insulin-like growth factor 1 in predominantly female patients with thyroid cancer: association with the histologic characteristics of the tumor. Endocr Pract 2016;22:68-75.

7. Cheng SP, Liu CL, Hsu YC, Chang YC, Huang SY, Lee JJ. Expression and biologic significance of adiponectin receptors in papillary thyroid carcinoma. Cell Biochem Biophys 2013;65:203-10.

8. Abella V, Pino J, Scotece M, Conde J, Lago F, GonzalezGay MA, et al. Progranulin as a biomarker and potential therapeutic agent. Drug Discov Today 2017;22:1557-64.

9. De Muynck L, Van Damme P. Cellular effects of progranulin in health and disease. J Mol Neurosci 2011;45:549-60.

10. Neill T, Buraschi S, Goyal A, Sharpe C, Natkanski E, Schaefer L, et al. EphA2 is a functional receptor for the growth factor progranulin. J Cell Biol 2016;215:687-703. 